$1975(12000 \mathrm{~km})$. Part of the work involved reshooting the same lines using a variety of techniques, with a view to improving the quality of the data acquired.

A total of $33000 \mathrm{~km}$ of seismic surveying has been undertaken since the oil industry started work offshore West Greenland. Under the terms of the prospecting licences granted prior to and including 1972, the data recorded under these licences were to be kept confidential for 15 years from date of receipt, but the Ministry for Greenland reserved the right to reduce the period of confidentiality to five years from the expiry of the license if the licensee did not subsequently obtain a petroleum concession in Greenland. Licences granted offshore West Greenland expired in 1972, and only some of the licensees subsequently obtained petroleum concessions. This means that some of the older seismic and other geophysical data will become publicly available during 1977 .

Once release dates have been reached both well data and geophysical data will become available through GGU.

Four wells are expected to be drilled offshore West Greenland in 1977. As part of the planning, detailed site surveys were made over nine possible well locations on behalf of the three groups planning to drill. The work comprised detailed bathymetric surveys, side-scan sonar surveys, seismic surveys designed to provide information on the section immediately below the sea floor and bottom sampling.

Representatives from one of the operating companies that visited the Nûgssuaq area during the summer of 1975 returned to the area in 1976 to examine additional sections and collect further material.

The Survey continued to be represented in the working group drawing up regulations to govern the activities of companies undertaking mineral exploration on land in Greenland and in adjacent marine areas. The 'Offshore Drilling Regulations' prepared by this group were published by the Ministry for Greenland in March 1976. The Survey also participated in a Ministry group that produced a television documentary on oil for showing in the Greenland towns.

During 1976 the Survey had numerous visits from representatives of groups holding offshore petroleum concessions and from geologists and other company representatives from companies interested in the other sedimentary areas onshore and offshore Greenland.

\title{
Continuation of the aeromagnetic surveys in southern and central West Greenland between $64^{\circ}$ and $72^{\circ} \mathrm{N}$
}

\section{Leif Thorning}

In the summer of 1976 the aeromagnetic surveys, started in 1975 (Thorning, 1976), were continued. The aircraft type, most of the instrumentation and the general logistic arrangements were as in 1975. Base of operations was again Søndre Strømfjord Air Base. The airborne system was improved by the addition of a radar altimeter with a better performance 
and a range of $5000 \mathrm{ft}$. The digital recording system could bee given manual input and this was utilised to get an in-flight digital registration of barometric altitude.

The summer was characterised by long periods of bad weather or severe disturbances in the geomagnetic field, and this prevented flying on many days. However, a substantial amount of data (approximately 22000 line kilometres) has been collected and this is now being compiled in the AM data base together with the data from 1975.

This note gives a brief description of the 1976 surveys; the total coverage, apart from some single more northerly flights from this and the 1975 survey is indicated in fig. 11.

\section{Region between $67^{\circ}$ to $68^{\circ} 15^{\prime} \mathrm{N}$}

The major part of the 1976 operations took place in the region north of Holsteinsborg and Søndre Strømfjord, containing Nagssugtûp nûna, Nordre Strømfjord and Arfersiorfik (region NA on fig. 11). The survey was flown with a $1.5 \mathrm{~km}$ spacing at a constant altitude of $3000 \mathrm{ft}$. The recorded aeromagnetic field exhibits a considerable degree of variation although there are no really outstanding anomalies. In general, the strike of the anomalies agrees very well with the observed or inferred geological strike. The large anomaly observed last year near Holsteinsborg (north-western corner of area SS) can be followed all the way to the Inland Ice by a series of anomalies of large amplitude. In some places the aeromagnetic field seems to indicate that a revision of the geological boundaries may be necessary. The quartz dolerite complex at the bottom of Arfersiorfik at Nunatarujuk, the gneiss complex near the Usugdlûp sermia glacier, and the boundary between two gneiss types with amphibolites in a radial structure situated at Kangârsup, north of Holsteinsborg, all have associated large amplitude anomalies. In the region with relatively high mountains north-east of Holsteinsborg no valid data was obtained due to poor flying conditions.

\section{Nûgssuaq-Disko-Svartenhuk Halvф}

Six profiles with $3 \mathrm{~km}$ spacing were flown over Nûgssuaq from the Inland Ice to the tip of the peninsula (NU on fig.11). The altitude was $6000-6500 \mathrm{ft}$. just clearing the highest summits. The eastern part of these profiles shows a smooth field increasing to the west with a gradient that can probably be accredited to the main dipole field. In the western part the effect of the lavas can be seen very clearly as negative anomalies suggesting that the bulk of the lava flows are reversely magnetised. A profile running from Nûgssuaq over Hareøen and the western parts of Disko and other profiles over the Vaigat and the Umanak Fjord exhibits the same effect. A planned detailed survey over an isolated, sharp magnetic anomaly detected on last year's reconnaissance flights - at Itivdlavssup qaqâ, north of the Torssukatak fjord, had to be abandoned.

\section{Nordlandet}

In 1975 the survey over Nordlandet (AK on fig. 11) could not be finished due to bad weather. This year the survey was completed by recording the remaining twenty-five profiles. The general picture of the aeromagnetic field is as determined in $\mathbf{1 9 7 5 .}$ 


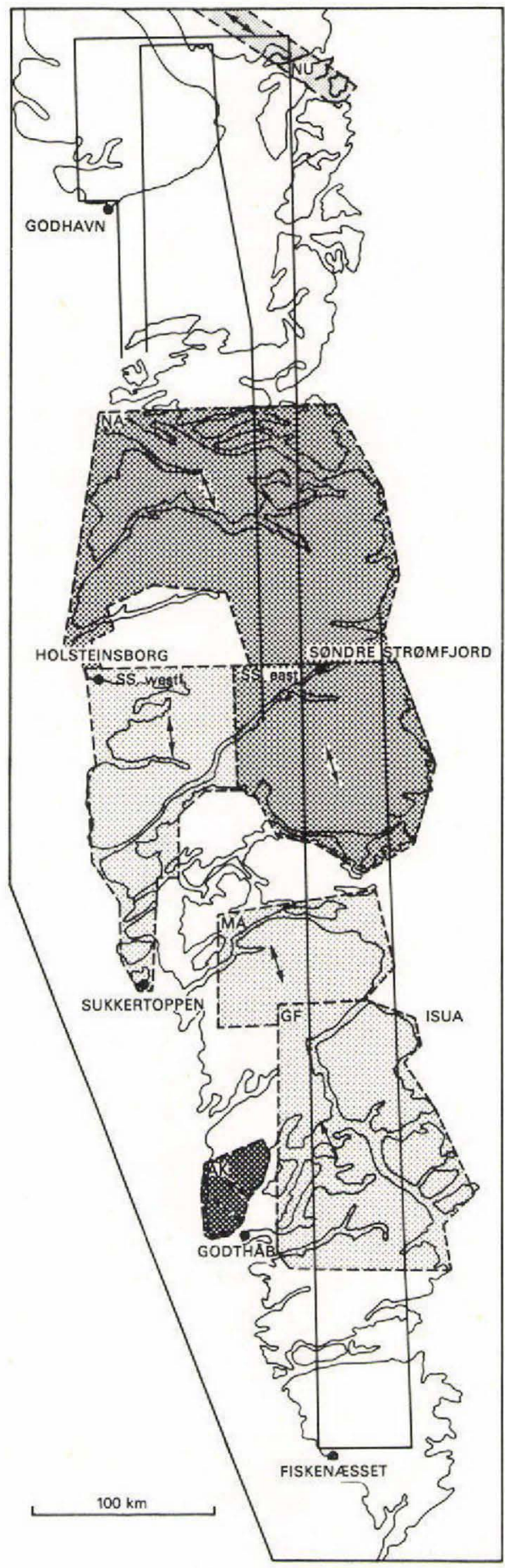

Fig. 11. Aeromagnetic survey coverage in West Greenland carried out in 1975 and 1976. In 1976, approximately 22000 line kilometres were flown in areas designated $\mathrm{NA}$ and $\mathrm{NU}$ and in the southern part of $\mathrm{AK}$, as well as some single profiles over Disko-Nûgssuaq-Umanak Fjord (not on the figure). The density of stippling indicates the relative intensity of profiles, and the arrows indicate profile direction. 


\section{Future work}

No further aeromagnetic flights have been planned for the next couple of years but the follow-up ground work will start in 1977. Already in 1975-1976 a number of localities around Søndre Strømfjord andQôrqut in Godthåbsfjord have been visited and susceptibility values have been obtained. In 1977 several key areas will be visited. Magnetic ground surveys will be carried out over selected anomalies with the purpose of determining the source of the aeromagnetic anomalies. Susceptibilities will be measured in the field, and a collection of oriented samples will be gathered for rock magnetic studies to provide necessary information for more detailed interpretation of the aeromagnetic data. The collected samples will probably also be used in palaeomagnetic studies.

\section{Acknowledgements}

The two-year aeromagnetic programme in West Greenland has been a team effort involving other than GGU personnel. The Electronics Department of the Danish Atomic Energy Commission's Research Establishment, Ris $\emptyset$, has been responsible for most of the instrumental developments. In the field, E. Mose Christiansen, E. Hansen and S. Frost have almost constantly kept the instrumental system at peak performance under the often difficult arctic conditions. V. Søndergård, C. Marcussen, E. Nielsen, from University of Århus, and E. Hansen from GGU ably assisted in the base camp as well as under measuring flights. The pilots from Vængir Airtransport Co., Iceland, - T. Magnusson, B. Hjaltason, J. Valdimarson and A. Christiansen - carried out their work in a highly effective way and usually with great enthusiasm. Flight mechanic L. Atlason has competently ensured the maximum flying possibilities by carrying out the servicing of the aircraft at night.

\section{Reference}

Thorning, L. 1976: Aeromagnetic surveys in southern and central West Greenland between $63^{\circ}$ and $71^{\circ}$ N. Rapp. Grønlands geol. Unders. 80, 61-65.

\section{A brief description of the computer programs used by GGU in the treatment of aeromagnetic data}

\section{Leif Thorning}

Computer programs for the treatment of aeromagnetic data have been developed parallel to GGU's acquisition and compilation of basic aeromagnetic data. The first data were collected in East Greenland in 1974 (Larsen, 1975), followed in 1975 and 1976 by the systematic regional survey of parts of the west coast (Thorning, 1976; this report). The first programs of the system had been designed by the end of 1974 and since then there has been a 